\title{
Analgesia Pós-Operatória Multimodal em Cirurgia Ginecológica Videolaparoscópica Ambulatorial. Comparação entre Parecoxib e Tenoxicam *
}

\author{
Multimodal Analgesia in Outpatient Videolaparoscopic Gynecologic \\ Surgery. Comparison between Parecoxib and Tenoxicam \\ Sérgio D. Belzarena TSA ${ }^{1}$; Mozart T. Alves ${ }^{2}$; Máximo L. D. Cucco ${ }^{2}$; Vanius D. D'Ávila ${ }^{2}$
}

\begin{abstract}
RESUMO
Belzarena SD, Alves MT, Cucco MLD, D’Ávila VD - Analgesia Pós-Operatória Multimodal em Cirurgia Ginecológica Videolaparoscópica Ambulatorial. Comparação entre Parecoxib e Tenoxicam
\end{abstract}

JUSTIFICATIVA E OBJETIVOS: Avaliar as características da analgesia pós-operatória em pacientes submetidas à cirurgia ginecológica videolaparoscópica ambulatorial, comparando o efeito de parecoxib e tenoxicam venoso em um estudo duplamente encoberto.

MÉTODO: Foram estudadas, prospectivamente, 60 pacientes divididas aleatoriamente em 2 grupos. Todas receberam sedação pré-operatória com midazolam. Um dos grupos $(P)$ recebeu, antes de iniciar a cirurgia, $40 \mathrm{mg}$ de parecoxib e o outro (T) $20 \mathrm{mg}$ de tenoxicam. Na sala de operação foi feita raquianestesia com bupivacaína e sufentanil. A analgesia pós-operatória foi avaliada mediante a intensidade da dor com escalas verbal e visual, a localização da dor (incisional, visceral, no ombro) e o consumo de analgésicos suplementares. Os efeitos colaterais adversos foram registrados. A satisfação da paciente com a técnica foi pesquisada.

RESULTADOS: A qualidade analgésica foi excelente, com $76 \%$ das pacientes do grupo $P$ e $83 \%$ das pacientes do grupo $T$ sem queixa de dor nem uso de analgésicos no pós-operatório. Não houve diferença entre os grupos em todos os critérios e períodos de avaliação analgésica. A incidência de efeitos adversos foi pequena, embora prurido de intensidade leve e curta duração tenha ocorrido freqüentemente. Todas as pacientes ficaram satisfeitas ou muito satisfeitas com a técnica empregada.

CONCLUSÕES: Uma técnica de analgesia multimodal, com um componente de anestésico local e opióide por via subaracnóidea associado a AINE venoso, produz analgesia pós-operatória de excelente qualidade com poucos efeitos colaterais adversos em cirurgia videolaparoscópica ginecológica ambulatorial. A escolha do AINE não parece importante para obter estes resultados.

\footnotetext{
* Recebido do (Received from) Serviço de Anestesiologia do Centro Hospitalar Santanense, Livramento, RS

1. Anestesiologista

2. Cirurgião Especialista em Videolaparoscopia
}

Apresentado (Submitted) em 12 de julho de 2004

Aceito (Accepted) para publicação em 12 de novembro de 2004

Endereço para correspondência (Correspondence to)

Dr. Sérgio D. Belzarena

Rua José Américo Domingues 96

97574-710 Livramento, RS

E-mail:sbelza@adinet.com.uy

(C) Sociedade Brasileira de Anestesiologia, 2005
Unitermos: ANALGÉSICOS, Antiinflamatório não hormonal: parecoxib, tenoxicam, ANESTESIA, Raquianestesia; CIRURGIA, Ambulatorial

\section{SUMMARY}

Belzarena SD, Alves MT, Cucco MLD, D’Ávila VD - Multimodal Analgesia in Outpatient Videolaparoscopic Gynecologic Surgery. Comparison between Parecoxib and Tenoxicam

BACKGROUND AND OBJECTIVES: The quality of postoperative analgesia in patients submitted to outpatient videolaparoscopic gynecologic surgery was evaluated by comparing the effects of intravenous parecoxib and tenoxicam in a double-blind study.

METHODS: Participated in this prospective study 60 patients who were randomly divided into two groups. All patients were premedicated with midazolam and one group $(P)$ received 40 $m g$ parecoxib before surgery. The other group $(T)$ received 20 $\mathrm{mg}$ tenoxicam in the same manner. Spinal anesthesia with bupivacaine and sufentanil was administered for videolaparoscopic gynecologic procedures. Postoperative analgesia was evaluated using verbal and visual scales. Pain site (incisional, visceral or shoulder), supplemental analgesics and side effects were recorded, in addition to patients' satisfaction with the technique.

RESULTS: Analgesic quality was excellent with $76 \%$ Group $P$ patients and $83 \%$ group $T$ patients with no postoperative pain complaint or analgesic request. There were no statistical differences between groups in all evaluated criteria. Pruritus, although brief and mild, was the primary side effect. All patients were satisfied or very satisfied with the technique.

CONCLUSIONS: Multimodal analgesia with subarachnoid local ane sthetic and opioid associated to intravenous NSAID produces excellent postoperative pain relief with few adverse effects in outpatient videolaparoscopic gynecologic surgery. The choice of the NSAID seems to be of minor importance for such results.

Key Words: ANALGESICS, Anti-inflammatory non hormonal: parecoxib, tenoxicam, ANESTHESIA, Spinal block; SURGERY, Outpatient

\section{INTRODUÇÃO}

definição da existência de duas isoformas da enzima ciclooxigenase, uma principalmente constitucional (isoforma 1 ou COX-1) e outra principalmente induzida pela inflamação (isoforma 2 ou COX-2) permitiu a criação de fármacos que inibem, preferencialmente, uma ou outra ou ambas. Como se aceita que a COX-1 desempenha papel fisiológico importante na função renal, plaquetária e gástrica, os inibidores específicos da COX-2 teriam efeitos mais 
benéficos em pacientes que precisam usar antiinflamatórios de forma aguda ou crônica ${ }^{1-3}$.

O parecoxib é um inibidor específico da COX-2 com um perfil farmacocinético e farmacológico que pode ser útil em Anestesiologia. Entre outras vantagens está incluída a possibilidade de administração por via venosa ${ }^{4.5}$.

Entre os fármacos há anos disponíveis, o tenoxicam é um inibidor não-específico da ciclooxigenase que também pode ser injetado por via venosa e é utilizado em analgesia pós-operatória ${ }^{6,7}$.

O presente estudo tem por objetivo comparar a ação analgésica e os efeitos adversos, da administração pré-operatória de parecoxib ou tenoxicam, em pacientes submetidas a procedimentos videolaparoscópicos ginecológicos ambulatoriais com a técnica de analgesia pós-operatória multimodal.

\section{MÉTODO}

O estudo foi aprovado pela Comissão de Ética do hospital (Centro Hospitalar Santanense) além de ter sido obtido o consentimento das pacientes, após informações.

Foram selecionadas 60 pacientes que seriam submetidas a procedimentos ginecológicos videolaparoscópicos em regime ambulatorial. O critério de exclusão prévia incluiu pacientes com diabetes, doença renal ou gastrintestinal preexistente ou alterações do número ou função plaquetária e aquelas que tivessem usando antiinflamatórios não-esteróides (AINE).

Aanestesia foi realizada com a monitorização habitual: ECG, $\mathrm{SpO}_{2}$, pressão não-invasiva automática. As pacientes receberam sedação pré-operatória na ante-sala com 2 a $3 \mathrm{mg}$ de midazolam venoso e, a seguir, foram administrados, de forma duplamente encoberta, $40 \mathrm{mg}$ de parecoxib ou $20 \mathrm{mg}$ de tenoxicam. As drogas foram administradas 5 minutos antes de encaminhar a paciente à sala de cirurgia por uma enfermeira, de acordo com uma instrução contida num envelope que indicava qual seria o AINE, a partir de uma lista gerada em computador.

Na sala de cirurgia foi realizada a raquianestesia na posição de decúbito lateral com uma agulha calibre $27 \mathrm{G}$ e administração de $15 \mathrm{mg}$ de bupivacaína hiperbárica a $0,5 \%$ com $5 \mu \mathrm{g}$ de sufentanil. Quando a sedação era insuficiente, foram administrados 1 a $2 \mathrm{mg}$ de midazolam, por via venosa.

Os procedimentos incluíram salpingectomia, ooforoplastia, miomectomia e lise de aderências por videolaparoscopia e excluíram os procedimentos exclusivamente diagnósticos. Aavaliação da dor pós-operatória incluiu sua localização (no ombro, incisional e visceral) e intensidade. A intensidade foi avaliada por escala verbal de 5 termos: ausente, leve, moderada, forte e muito forte e pela escala analógica visual de 100 $\mathrm{mm}$.

Aavaliação pós-operatória da dor foi feita 30, 120 e 240 minutos após o ingresso na sala de recuperação, antes da alta hospitalar e 48 horas após o procedimento.

A dor foi tratada inicialmente com dipirona $(1 \mathrm{~g})$ por via venosa e, se necessário, com fentanil venoso $(25 \mu \mathrm{g})$. Náuseas e vômitos foram tratados inicialmente com metoclopramida
(10 mg), por via venosa e, quando necessário, com $4 \mathrm{mg}$ de ondansetron venoso. As doses e horários de qualquer medicação administrada no pós-operatório foram registrados. Efeitos adversos no local de administração ou sistêmicos foram pesquisados até a alta hospitalar e após 48 horas, quando as pacientes retornaram para consulta com o cirurgião. O grau de satisfação com a técnica foi aferido por uma escala com as seguintes afirmações: não satisfeita, pouco satisfeita, satisfeita, muito satisfeita, também às 48 horas de pós-operatório.

A análise estatística dos dados colhidos foi feita com teste $t$ de Student para medidas continuas e o teste de $U$ de Mann-Whitney foi usado em medidas intervalares (dados ordinais). Dados categóricos foram analisados com teste de Qui-quadrado. Valores de $p$ menor que 0,05 foram considerados significativos.

\section{RESULTADOS}

Não houve diferença entre os grupos em relação aos dados antropométricos nem ao tipo de cirurgia (Tabela I).

Tabela I - Dados Antropométricos e das Cirurgias

\begin{tabular}{lcc}
\hline & Grupo P & Grupo T \\
\hline Idade $(\mathrm{anos})^{*}$ & $32 \pm 4$ & $35 \pm 4$ \\
Peso $(\mathrm{kg})^{*}$ & $67 \pm 6$ & $62 \pm 6$ \\
Altura $(\mathrm{cm}){ }^{*}$ & $158 \pm 9$ & $162 \pm 7$ \\
Tipos de cirurgias \# & & \\
$\quad$ Salpingectomia & 14 & 16 \\
Ooforoplastia & 8 & 6 \\
Miomectomia & 2 & 3 \\
Lise de aderências & 2 & 2 \\
Combinadas & 4 & 3 \\
\hline
\end{tabular}

* Valores expressos em Média \pm DP

\# Número de pacientes

Amaioria das pacientes não apresentou queixa de dor durante o período de avaliação. Não houve diferença entre os grupos, sendo que 23 (76\%) do grupo P e 25 (83\%) do grupo T não referiram dor nem usaram analgésicos suplementares. Entre as pacientes que manifestaram dor, ( 7 do grupo $P$ e 5 do grupo T), a localização foi diferenciada, majoritariamente no ombro e nenhuma incisional. A avaliação nas escalas verbal e visual mostrou que não havia pacientes com dor na primeira entrevista (aos 30 minutos da chegada na SRPA) e que ocorria com intensidade predominantemente leve ou moderada aos 120 minutos, diminuindo posteriormente na última observação aos 240 minutos, prévio à alta hospitalar. Não houve diferença entre os grupos na avaliação da intensidade da dor nem no consumo de analgésicos suplementares (Tabelas II e III).

A incidência de efeitos adversos foi alta em relação ao prurido e menor em relação à náusea e vômito, sem diferença entre os grupos (Tabela IV). 
Tabela II - Incidência da Dor

\begin{tabular}{lcc}
\hline & Grupo $\mathrm{P}(\mathrm{n})$ & Grupo $\mathrm{T}(\mathrm{n})$ \\
\hline Sem queixa de dor & 23 & 25 \\
Com dor de tipo & & \\
$\quad$ Incisional & 0 & 0 \\
Visceral & 2 & 1 \\
No ombro & 5 & 4 \\
Combinadas & 1 & 1 \\
\hline
\end{tabular}

(n) número de pacientes

Tabela III - Características da Intensidade da Dor e Consumo de Analgésicos

\begin{tabular}{|c|c|c|c|c|c|c|}
\hline \multirow[b]{2}{*}{ Escala verbal \# } & \multicolumn{3}{|c|}{ Grupo P } & \multicolumn{3}{|c|}{ Grupo T } \\
\hline & 30 & 120 & 240 & 30 & 120 & 240 \\
\hline Leve & 0 & 4 & 2 & 0 & 2 & 2 \\
\hline Moderada & 0 & 1 & 1 & 0 & 3 & 1 \\
\hline Forte & 0 & 2 & 0 & 0 & 0 & 0 \\
\hline Muito forte & 0 & 0 & 0 & 0 & 0 & 0 \\
\hline \multirow[t]{2}{*}{ Escala visual * } & 120 & & 240 & 120 & & 240 \\
\hline & $3,1 \pm 0,88$ & & $\pm 0,36$ & $2,8 \pm 0,75$ & & $4 \pm 0,21$ \\
\hline \multicolumn{7}{|l|}{ Analgésicos ${ }^{* *}$} \\
\hline Dipirona & \multicolumn{3}{|c|}{$8(1,14)$} & \multicolumn{3}{|c|}{$7(1,4)$} \\
\hline Fentanil & \multicolumn{3}{|c|}{0} & \multicolumn{3}{|c|}{0} \\
\hline
\end{tabular}

* Média \pm DP

\# Número de pacientes

** Número de doses (média)

Tabela IV - Efeitos Adversos

\begin{tabular}{lcc}
\hline & Grupo P & Grupo T \\
\hline Prurido & 16 & 18 \\
Náusea & 1 & 2 \\
Vômito & 4 & 3 \\
\hline
\end{tabular}

A avaliação final das pacientes sobre a qualidade da anestesia recebida só incluiu os itens - satisfeita e muita satisfeita sem diferença entre os grupos.

\section{DISCUSSÃO}

Os dois principais resultados deste estudo indicam que não foi encontrada diferença significativa entre o parecoxib e o tenoxicam, em relação ao efeito analgésico no pós-operatório dos procedimentos ginecológicos incluídos e que a técnica de analgesia multimodal selecionada foi apropriada. Há várias diferenças farmacológicas entre o parecoxib e o tenoxicam. Entre elas destaca-se a duração de ação (maior no tenoxicam), a especificidade do bloqueio das isoformas da ciclooxigenase (igual para a COX-1 e COX-2 com o tenoxicam). Desta forma, haveria vantagens com o uso do parecoxib que é um inibidor específico da isoforma induzida pela inflamação num procedimento em que a duração do efeito do fármaco não teria importância fundamental. Apesar disso, não houve diferença entre os grupos estudados na qualidade da analgesia obtida. Este fato pode ser devido à associação com anestésico local e opióide administrados por via subaracnóidea (técnica de analgesia pós-operatória multimodal) ou a que o controle da dor necessite de bloqueio das duas isoformas da ciclooxigenase ${ }^{8,9}$.

A dor pós-operatória em cirurgias ginecológicas videolaparoscópicas é um problema importante devido ao caráter ambulatorial dos procedimentos ${ }^{10}$. Em particular a salpingectomia tem sido caracterizada como dolorosa, havendo diversos autores que propõem alternativas, como o uso de clip de Hulka ou o anel de Yoong. No entanto, a retirada da trompa parece ser mais efetiva quando o que se procura é a esterilização da paciente ${ }^{11-13}$. Nos estudos mencionados foi utilizada anestesia geral e os dados do presente estudo demonstram que a raquianestesia foi um dos componentes essenciais para o resultado analgésico conseguido, sendo que o resultado inicial (avaliação de todas as pacientes "sem dor" aos 30 minutos) pode ser atribuído ao efeito residual da anestesia espinhal. Como também há outro estudo que mostra que a raquianestesia é economicamente mais conveniente para este tipo de cirurgia, nosso resultado sugere que esta poderia ser a técnica de escolha nesta situação ${ }^{14}$. Coincidentemente, neste último estudo, $75 \%$ das pacientes do grupo da raquianestesia não solicitou analgésicos no período pós-operatório, comparada com $25 \%$ das que receberam anestesia geral ${ }^{14}$.

A técnica de analgesia multimodal tenta somar efeitos benéficos de analgésicos que atuam em diferentes locais tentando ao mesmo tempo diminuir os efeitos adversos. Esta técnica que combina o efeito espinhal da bupivacaína, com os efeitos espinhal e sistêmico do sufentanil e os efeitos periférico e central dos inibidores da ciclooxigenase mostrou que é eficaz para alivio da dor pós-operatória, necessitando de mais avaliações, com maior número de pacientes para determinar se outros benefícios próprios das técnicas multimodais são observados ${ }^{15,16}$.

Uma crítica que poderia ser feita ao desenho do método é a ausência de um grupo controle, com placebo em lugar dos AINE. No entanto, existem inúmeras publicações que atestam a melhor qualidade da analgesia e a redução no uso de analgésicos opióides quando se administram AINE. A maioria dos estudos publicados comparando parecoxib ou tenoxicam com placebo concluiu que os pacientes que recebem o AINE têm melhor analgesia pós-operatória ${ }^{4-7}$. Esta é a justificativa para não incluir um grupo de pacientes tratado com placebo.

Não foram detectados efeitos adversos que tenham algum tipo de vínculo com os AINE utilizados neste grupo de pacientes, embora o poder do estudo para este tipo de constatação é insuficiente, já que seria necessário um número muito maior de participantes para determinar a incidência e comparar parecoxib e tenoxicam neste sentido. Entre os poucos efeitos adversos detectados, o prurido ocorreu em mais da metade das pacientes (34 em 60, 16 no grupo $P$ e 18 no grupo $T$ sem diferença). Sempre foi de intensidade leve ou moderada e de curta duração, não superior a 2 horas em nenhum caso, não sendo necessário tratamento para reverter sua ação. Vol. 55, Nº 2, Março - Abril, 2005 
Pelas características, só pode ser atribuído ao sufentanil administrado na raquianestesia.

Aincidência de náusea ( 1 paciente no grupo $P$ e 2 no grupo $T$ ) e vômito (4 pacientes no grupo $\mathrm{P}$ e 3 no grupo $\mathrm{T}$ ) foi pequena em comparação a outros estudos publicados neste tipo de cirurgia, quando foi usada a anestesia geral ${ }^{17,18}$. Se a raquianestesia foi importante para diminuir estas complicações, não pode ser definido com o número de pacientes avaliado. Como náusea e vômito têm muita importância em cirurgia ambulatorial, são necessários outros estudos para esclarecimento, no entanto, a anestesia regional é um fator reconhecido para diminuir estes efeitos adversos ${ }^{14,19}$. Um estudo em animais sugeriu que o centro do vômito é influenciado por prostaglandinas e que o uso de inibidores da COX tem ação antiemética ${ }^{20}$.

Em conclusão, a analgesia pós-operatória de pacientes de cirurgias ginecológicas ambulatoriais videolaparoscópicas com esta técnica multimodal, que inclui a utilização de anestésico local e opióide por via subaracnóidea e AINE, por via sistêmica, apresenta boa qualidade, com a maioria das pacientes sem queixa de dor nem uso suplementar de analgésicos. Os efeitos colaterais adversos foram poucos e não interferiram com o caráter ambulatorial do procedimento. AescoIha do tipo de AINE, específico para inibição da COX-2 (parecoxib) ou inespecífico (tenoxicam) foi irrelevante.

\section{Multimodal Analgesia in Outpatient Videolaparoscopic Gynecologic Surgery. Comparison between Parecoxib and Tenoxicam}

Sérgio D. Belzarena TSA, M.D.; Mozart T. Alves, M.D.; Máximo L. D. Cucco, M.D.; Vanius D. D’Ávila, M.D.

\section{INTRODUCTION}

The definition of the presence of two cycloxygenase enzyme isoforms, one primarily constitutional (isoform 1 or COX-1) and the other primarily inflammation-induced (isoform 2 or COX-2) has allowed the development of drugs preferably inhibiting the former, the latter or both. Since it is accepted that COX-1 plays important physiological role in renal, platelet and gastric function, specific COX-2 inhibitors would be more beneficial for patients needing acute or chronic anti-inflammatory drugs ${ }^{1-3}$.

Parecoxib is a specific COX-2 inhibitor with pharmacological and pharmacokinetic profile which may be useful in Anesthesia. The possibility of intravenous administration is one of its advantages $^{4,5}$.

Among drugs available for a long time, tenoxicam is a non-specific cycloxygenase inhibitor which may be also intravenously administered and is used for postoperative analgesia $^{6,7}$.
This study aimed at comparing analgesic action and adverse effects of preoperative parecoxib or tenoxicam in patients submitted to outpatient gynecologic videolaparoscopy with multimodal postoperative analgesia.

\section{METHODS}

After the hospital's Ethics Committee approval (Centro Hospitalar Santanense) and their informed consent, participated in this study 60 patients scheduled for outpatient gynecologic videolaparoscopy. Exclusion criteria were diabetes, renal or GI diseases or changes in platelet number or function, in addition to those having used NSAIDs.

Anesthesia was performed under typical monitoring: ECG, $\mathrm{SpO}_{2}$ and automatic noninvasive blood pressure. Patients were premedicated with 2 to $3 \mathrm{mg}$ intravenous midazolam. Next, $40 \mathrm{mg}$ parecoxib or $20 \mathrm{mg}$ tenoxicam were administered in a double-blind manner. Drugs were administered by a nurse 5 minutes before referring patients to the operating room and according to instructions in an envelope indicating the NSAID as from a computer-generated list.

Spinal anesthesia was performed in the operating room with the patient in the lateral position with $27 \mathrm{G}$ needle and $15 \mathrm{mg}$ of $0.5 \%$ hyperbaric bupivacaine plus $5 \mu \mathrm{g}$ sufentanil. When sedation was insufficient, 1 to $2 \mathrm{mg}$ intravenous midazolam were administered.

Procedures included videolaparoscopic salpyngectomy, oophoroplasty, miomectomy and adherences lysis and excluded exclusively diagnostic procedures.

Postoperative pain evaluation included site (shoulder, incision or visceral) and intensity. Intensity was evaluated by a verbal scale with 5 words: absent, mild, moderate, severe and very severe, and by $100 \mathrm{~mm}$ visual analog scale.

Postoperative pain was evaluated 30,120 and 240 minutes after admission to the recovery room, before hospital discharge and 48 hours after the procedure.

Pain was initially treated with intravenous dipirone $(1 \mathrm{~g})$ and, if necessary, with intravenous fentanyl $(25 \mu \mathrm{g})$. Nausea and vomiting were initially treated with intravenous metochlopramide (10 mg) and, when necessary, with $4 \mathrm{mg}$ intravenous ondansetron. Doses and time for any postoperative drug were recorded.

Local or systemic adverse effects were investigated until hospital discharge, and then at 48 hours when patients returned to be evaluated by the surgeon.

Level of satisfaction with the technique was evaluated 48 hours after surgery by a scale with the following statements: not satisfied, moderately satisfied, satisfied, very satisfied.

Student's $t$ test was used for continuous measurements and Mann-Whitney's U test for interval measures (ordinal data). Chi-square test was used for categorical data. $p$ values below 0.05 were considered significant.

\section{RESULTS}

There were no differences between groups in demographics or type of surgery (Table I). 
Table I - Demographics Data and Surgery Type

\begin{tabular}{lcc}
\hline & Group P & Group T \\
\hline Age (years) * & $32 \pm 4$ & $35 \pm 4$ \\
Weight $(\mathrm{kg})^{*}$ & $67 \pm 6$ & $62 \pm 6$ \\
Height $(\mathrm{cm})^{*}$ & $158 \pm 9$ & $162 \pm 7$ \\
Surgery type \# & & \\
$\quad$ Salpyngectomy & 14 & 16 \\
$\quad$ Oophoroplasty & 8 & 6 \\
$\quad$ Miomectomy & 2 & 3 \\
Adherence lysis & 2 & 2 \\
Combined & 4 & 3 \\
\hline
\end{tabular}

*Values in Mean $\pm \mathrm{SD}$

\# Number of patients

Most patients had no pain during the evaluation period. There have been no differences between groups, and 23 (76\%) group $\mathrm{P}$ and 25 (83\%) group T patients have not referred pain or requested supplemental analgesics. Among patients referring pain ( 7 in group $P$ and 5 in group $T$ ) most of them related having shoulder pain but no one referred incisional pain. Verbal and visual scale evaluation has shown that there were no patients referring pain 30 minutes after PACU arrival, and that pain was predominantly mild or moderate at 120 minutes, decreasing at 240 minutes. There were no differences between groups in pain intensity or supplemental analgesics (Tables II and III).

Table II - Incidence of Pain

\begin{tabular}{lcc}
\hline & Group P (n) & Group T (n) \\
\hline Without pain & 23 & 25 \\
With pain on & & \\
Incision & 0 & 0 \\
Visceral & 2 & 1 \\
Shoulder & 5 & 4 \\
Combined & 1 & 1 \\
\hline
\end{tabular}

(n) number of patients

Table III - Pain Intensity and Analgesic Consumption

\begin{tabular}{ccccccc}
\hline & \multicolumn{3}{c}{ Group P } & \multicolumn{3}{c}{ Group T } \\
\hline Verbal Scale \# & 30 & 120 & 240 & 30 & 120 & 240 \\
\hline Mild & 0 & 4 & 2 & 0 & 2 & 2 \\
Moderate & 0 & 1 & 1 & 0 & 3 & 1 \\
Severe & 0 & 2 & 0 & 0 & 0 & 0 \\
Very severe & 0 & 0 & 0 & 0 & 0 & 0 \\
\hline Visual Scale * & 120 & 240 & 120 & 240 \\
\hline Analgesics** & $3.1 \pm 0.88$ & $1.6 \pm 0.36$ & $2.8 \pm 0.75$ & $1.4 \pm 0.21$ \\
Dipirone & $8(1.14)$ & & & \\
Fentanyl & 0 & & & 0 \\
\hline
\end{tabular}

* Mean $\pm \mathrm{SD}$

\# Number of patients

** Number of doses (mean)

162
There has been high incidence of pruritus and low incidence of nausea and vomiting, without differences between groups (Table IV).

Table IV - Adverse Effects

\begin{tabular}{lcc}
\hline & Group P & Group T \\
\hline Pruritus & 16 & 18 \\
Nausea & 1 & 2 \\
Vomiting & 4 & 3 \\
\hline
\end{tabular}

Patients' satisfaction with the technique has only included the words satisfied and very satisfied, without differences between groups.

\section{DISCUSSION}

Our two major results have shown no significant difference in postoperative analgesia with parecoxib or tenoxican for gynecologic procedures, and that multimodal analgesia has been an adequate technique.

There are several pharmacological differences between parecoxib and tenoxicam, among them duration of action (longer for tenoxicam), and specificity for cycloxygenase isoforms blockade (equal for COX-1 and COX-2 for tenoxicam). So, there would be advantages for parecoxib, which is a specific inhibitor of the inflammation-induced isoform, in a procedure where drug effect duration would not be of primary importance. Nevertheless, there were no differences between groups. This could have been due to the association of subarachnoid local anesthetic and opioid (postoperative multimodal analgesia) or to the fact that pain control requires the blockade of both cycloxygenase isoforms ${ }^{8,9}$. Pain after gynecologic videolaparoscopies is a major problem because these are outpatient procedures ${ }^{10}$. Salpyngectomy has been particularly defined as painful and several alternatives have been proposed such as Hulka's clip or Yoong's ring. However, tube removal seems to be more effective when the aim is patient's sterilization ${ }^{11-13}$. The above-mentioned studies have used general anesthesia and our data show that spinal anesthesia was an essential component for the analgesic result. The initial result (all patients referring "no pain" at 30 minutes) may be attributed to residual spinal anesthesia. Since there is another study showing that spinal anesthesia is more convenient for this type of surgery, our results suggest that this could be the technique or choice for this situation ${ }^{14}$. Similarly, in this latter study, $75 \%$ of spinal anesthesia patients have not requested postoperative analgesics, as compared to $25 \%$ of general anesthesia patients ${ }^{14}$.

Multimodal analgesia technique attempts to add beneficial effects of analgesics acting in different sites as well as to decrease the incidence of adverse effects. This technique combining bupivacaine's spinal effect, sufentanil's spinal and systemic effect, and peripheral and central effects of cycloxygenase inhibitors has proven to be effective for post-

Revista Brasileira de Anestesiologia Vol. 55, Nº 2, Março - Abril, 2005 
operative pain relief, but further evaluations with a larger number of patients are needed to determine whether other benefits of multimodal techniques are also observed ${ }^{15,16}$. A critic to our methodological design might be the absence of a placebo group. There are however several publications confirming higher analgesic quality and decreased opioid consumption when NSAIDs are administered. Most studies comparing parecoxib or tenoxicam to placebo have concluded that patients receiving NSAIDs have better postoperative analgesia ${ }^{4-7}$ and this was the reason for not including a placebo group in our study.

No adverse effects related to NSAIDs used in this group of patients were observed although the power of our study was not sufficient for this type of observation, since a much larger number of participants would be necessary to determine the incidence and relate it to parecoxib or tenoxicam. Among few observed side effects, pruritus was present in more than $50 \%$ of patients (34 out of 60, 16 in group P and 18 in group T without difference). It was always mild or moderate lasting no more than 2 hours and needing no treatment for its reversion. For its characteristics, it could only be attributed to sufentanil administered for spinal anesthesia.

The incidence of nausea (1 group $\mathrm{P}$ and 2 group T patients) and vomiting (4 group $\mathrm{P}$ and 3 group $T$ patients) was low as compared to other studies with this type of surgery however under general anesthesia ${ }^{17,18}$. Whether spinal anesthesia was important to decrease these complications could not be assessed with the number of evaluated patients. Since nausea and vomiting are very distrurbing complication in outpatient procedures, further studies are needed. However, it is known that regional anesthesia is a factor to decrease such adverse effects ${ }^{14,19}$. An animal study has suggested that the vomiting center is influenced by prostaglandins and that COX inhibitors have anti-emetic action ${ }^{20}$.

In conclusion, postoperative analgesia for outpatient gynecologic videolaparoscopies with this multimodal technique including subarachnoid local anesthetics and opioids, and systemic NSAIDs, is adequate with most patients without pain complaint or requesting additional analgesics. There were few side effects which have not interfered with the outpatient character of the procedure. The choice of the NSAID, specific for COX-2 inhibition (parecoxib) or nonspecific (tenoxicam) was irrelevant.

\section{REFERÊNCIAS - REFERENCES}

01. McCrory CR, Lindahl SG - Cyclooxygenase inhibition for postoperative analgesia. Anesth Analg, 2002;95:169-176.

02. Gilron I, Milne B, Hong M - Cyclooxigenase-2 inhibitors in postoperative pain management: current evidence and failure directions. Anesthesiology, 2003;99:1198-1208.

03. Souter AJ, Fredman B, White PF - Controversies in the perioperative use of nonsteroidal antiinflammatory drugs. Anesth Analg, 1994;79:1178-1190.
04. Desjardins PJ, Grossman EH, Kuss ME et al - The injectable cyclooxigenase-2- specific inhibitor parecoxib sodium has analgesic efficacy when administered preoperatively. Anesth Analg, 2001;93:721-727.

05. Tang J, Li S, White PF et al - Effect of parecoxib, a novel intravenous cyclooxygenase type- 2 inhibitor, on the postoperative opioid requirement and quality of pain control. Anesthesiology, 2002;96:1305-1309.

06. Belzarena SD - Tenoxicam venoso para prevenção da dor pós-operatória em cirurgia abdominal superficial. Rev Bras Anestesiol, 1994;44:175-180.

07. O'Hanlon DM, Thambipillai T, Colbert ST et al - Timing of pre-emptive tenoxicam is important for postoperative analgesia. Can J Anaesth, 2001;48:162-166.

08. Gilroy DW, Tomlinson A, Willoughby DA - Differential effects of inhibitors of cyclooxygenase (cyclooxygenase 1 and cyclooxygenase 2) in acute inflammation. Eur J Pharmacol, 1998;355:211-217.

09. Zhu X, Conklin D, Eisenach JC - Cyclooxigenase-1 in the spinal cord plays an important role in postoperative pain. Pain, 2003;104:15-23.

10. Jin FL, Chung F - Postoperative pain - a challenge for anaesthetists in ambulatory surgery. Can J Anaesth, 1998;45:293-296.

11. Dobbs FF, Kumar V, Alexander JI et al - Pain after laparoscopy related to posture and ring versus clip sterilization. $\mathrm{Br} \mathrm{J}$ Obstet Gynaecol, 1987;94:262-266.

12. McKenzie R, Phitayakorn P, Uy NT et al - Topical etidocaine during laparoscopic tubal occlusion for postoperative pain relief. Obstet Gynecol, 1986;67:447-449.

13. MacLennan AH, Rodrigues LV, Krutli DR et al - Post-operative discomfort after ring or clip tubal ligation - is there any difference and do indomethacin suppositories help? Contraception, 1990;42:309-313.

14. Chilvers CR, Goodwin A, Vaghadia H et al - Selective spinal anesthesia for outpatient laparoscopy. V: pharmacoeconomic comparison vs general anesthesia. Can J Anaesth, 2001;48:279-283.

15. Kehlet $\mathrm{H}$ - Multimodal approach to control postoperative pathophysiology and rehabilitation. Br J Anaesth, 1997;78:606-617.

16. Brodner G, Pogatzki E, Van Aken H et al - A multimodal approach to control postoperative pathophysiology and rehabilitation in patients undergoing abdominothoracic esophagectomy. Anesth Analg, 1998;86:228-234.

17. Purhonen S, Kauko M, Koski EM et al - Comparison of tropisetron, droperidol and saline in the prevention of postoperative nausea and vomiting after gynecologic surgery. Anesth Analg, 1997:84:662-667.

18. Graczyk SG, McKenzie R, Kallar S et al - Intravenous dolasetron for the prevention of postoperative nausea and vomiting after outpatient laparoscopic gynecologic surgery. Anesth Analg, 1997;84:325-330.

19. Carpenter RL, Liu S, Neal JM - Epidural anesthesia and analgesia. Their role in postoperative outcome. Anesthesiology, 1995;82:1474-1506.

20. Girod V, Bouvier M, Grelot L - Characterization of lipopolysaccharide - induced emesis in conscious piglets: effects of cervical vagotomy, cyclooxigenase inhibitors and $5-\mathrm{HT}(3)$ receptor antagonism. Neuropharmacology, 2000;39:2329-2335. 


\section{RESUMEN}

Belzarena SD, Alves MT, Cucco MLD, D’Ávila VD - Analgesia Pos-Operatoria Multimodal en Cirugía Ginecológica Videolaparoscópica Ambulatorial. Comparación entre Parecoxib y Tenoxican

JUSTIFICATIVA Y OBJETIVOS: Evaluar las características de la analgesia pos-operatoria en pacientes sometidas a cirugía ginecológica videolaparoscópica ambulatorial, comparando el efecto de parecoxib y tenoxican venoso en un estudio doblemente encubierto.

MÉTODO: Fueron estudiadas prospectivamente 60 pacientes divididas de forma aleatoria en 2 grupos. Todas recibieron sedación pre-operatoria con midazolan. Un de los grupos $(P)$ recibió antes de iniciar la cirugía $40 \mathrm{mg}$ de parecoxib y en el otro (T) $20 \mathrm{mg}$ de tenoxican. En la sala de operación fue hecha raquianestesia con bupivacaína y sufentanil. La analgesia pos-operatoria fue evaluada mediante la intensidad del dolor con escalas verbal y visual, localización del dolor (incisional, visceral, en el hombro) y el consumo de analgésicos suplementares. Fueron registrados los efectos colaterales adversos La satisfacción de la paciente con la técnica fue pesquisada.

RESULTADOS: La calidad analgésica fue excelente, con $76 \%$ de las pacientes del grupo $P$ y $83 \%$ de las pacientes del grupo $T$ sin queja de dolor y tampoco el uso de analgésicos en el pos-operatorio. No hubo diferencia entre los grupos en todos los criterios y períodos de evaluación analgésica. La incidencia de efectos adversos fue pequeña, no obstante, prurito de intensidad leve y de corta duración ocurrió frecuentemente. Todas las pacientes quedaron satisfechas o también muy satisfechas con la técnica empleada.

CONCLUSIONES: Una técnica de analgesia multimodal, con un componente de anestésico local y opioide por vía subaracnóidea asociado con AINE venoso produce analgesia pos-operatoria de excelente calidad con pocos efectos colaterales adversos en cirugía videolaparoscópica ginecológica ambulatorial. La elección del AINE no parece importante para la obtención de estos resultados. 